\title{
WHY MAKE FAKE BREASTMILK?
}

\author{
George Kent*
}

There are efforts underway to make "breastmilk" called Biomilq through cell culture, which means growing cells under controlled conditions (Invitrogen and Gibco. 2020). The Biomilq people say, "We're working to produce cultured human breastmilk using patent-pending technology in order to offer families a more nutritious and more sustainable option for feeding babies.” More nutritious than what? More sustainable than what? Why are they doing this? In the long and checkered history of innovation in infant feeding (Crowther, Reynolds, and Tansey 2009; Stevens, Patrick, and Pickler 2009), this does not look promising.

There is a similar attempt to develop a cultured infant feeding product by TurtleTree Labs ((Roy 2020; Turtletree Labs 2020; Watson 2020b). The focus in this paper is on Biomilq, but the same issues could be raised in relation to TurtleTree's project.

There is a great deal of commentary about Biomilq in the popular press, much of it from public relations firms (Biomilq 2020; Corbyn 2020; Egger and Strickland 2020; Jordan 2020; MartynHemphill 2020; Lamb 2020; Miller 2020; Peters, Adele 2020; Peters, Joshua 2020; Randall 2020; Roy 2020; Sklar 2020; Watson 2020a; Wuench 2020; Zhang 2020). There is no discussion of it in reputable scientific journals. Some question the project because of its linkage to the Bill and Melinda Gates Foundation (Children's Health Defense Team 2020. Also see Loffredo and Greenstein 2020; Malkan 2020; Schwab 2020). The Biomilq initiative is not related to the United States Department of Agriculture's project called MILQ (USDA 2020).

\section{HEALTH}

Serious assessment of a new feeding product for infants should not be based on its list of ingredients. It should be based on its actual performance in protecting and promoting health, primarily for the infant, but also for the mother. Assessments should be based on comparisons with the gold standard, optimal breastfeeding practices. How would the health impacts of using Biomilq compare with those from breastfeeding, or providing expressed breast milk, or using conventional infant formula? What would be the health risks involved in using Biomilq? So far, Biomilq advocates have not explained how they would assess the product (Kent 2019a).

The idea that human breastmilk can be synthesized is dangerous. United Nations agencies and many national government agencies recommend exclusive breastfeeding for six months, which means no other foods should be provided for that period (Victora et al. 2016; WHO 2018).

*George Kent, Deputy Editor of World Nutrition, is also its Curator of Good Questions. This is the twelfth in the Series. He is Professor Emeritus (Political Science) with the University of Hawaii, an Adjunct Professor with Saybrook University in California, and an Adjunct Professor with the University of Sydney in Australia. He can be reached at kent@hawaii.edu 
Feeding infants Biomilq alone for six months would be very risky. There is no good way to test Biomilq on infants.

Breastfeeding is a process while breastmilk is a product. Breastmilk can be delivered through the breastfeeding process, with important skin-to-skin contact and constant biodynamic communication between mother and infant that supports adjustment of the breastmilk to meet the needs of the infant, Breastmilk can be delivered through a bottle or cup, but neither supports the biodynamic breastfeeding process (Kent 2017a, 134-140; Kent 2019a; Thorley 2018). When United Nations agencies and national government agencies recommend exclusive breastfeeding for about six months, they are talking about biodynamically active breastfeeding, not just the passive delivery of a product during that time period.

\section{ENVIRONMENT}

One representative of Breakthrough Energy Ventures said Biomilq "not only offers a better solution for the environment, but will also improve nutrition for infants around the globe” (Randall 2020). Just as Biomilq supporters have not provided any evidence for this claim about "improving nutrition" they also have not explained how it would "offer a better solution for the environment.” A good deal of research has been done on the environmental impacts of production, marketing, and use of infant formula (IBFAN 2020) but none has been done on the likely environmental impact of the production, marketing, and use of Biomilq.

Biomilq advocates sometimes suggest that their the main objective is to reduce the environmental damage that results from raising cows to produce all the milk that goes into making conventional infant formula. Would fake breastmilk be better than, say, infant formula made with fake cow's milk (Watson 2020c)?

\section{MORE QUESTIONABLE CLAIMS}

The Biomilq website says, "Breastfeeding is hard for most \& impossible for many." (Biomilq 2020). They offer no evidence to support these claims. Only a small percentage of women are physiologically unable to breastfeed. Many women who do have difficulties can be helped by lactation counselors (Morrison 2018).

The website says, "More than 4 out of 5 moms have to stop breastfeeding before the recommended six months" (Biomilq 2020). Apparently, this is about the US, not the world as a whole. According to the US Centers for Disease Control and Prevention, "Among infants born in 2015 in the United States, 4 out of 5 (83.2\%) started to breastfeed, over half (57.6\%) were breastfeeding at 6 months" (CDC 2018). What was the basis for the their saying 4 out of 5 mothers stop breastfeeding by six months?

The Biomilq people say their system "allows us to create the full constellation of complex components in perfect proportion” (Randall 2020). That is a bit like saying my buckets of red, 
yellow, and blue paints, mixed together in the right proportions would ensure that my paintings will be as good as any Rembrandt painting.

Joshua Peters, a Biomilq supporter, acknowledges that the scientific basis for the claim that they can produce cell-based breastmilk has been exaggerated:

They haven't created a full replacement for breast milk yet, after all, just a cultured version that contains two of the major components of the original: lactose and casein. They take the presence of these two major components to mean that they are on the way to creating milk nutritionally equivalent to breast milk. (Peters, Joshua. 2020)

Finding a way to put two parts together hardly signals they are well on their way to producing a complicated living thing.

\section{IDENTITY ISSUES}

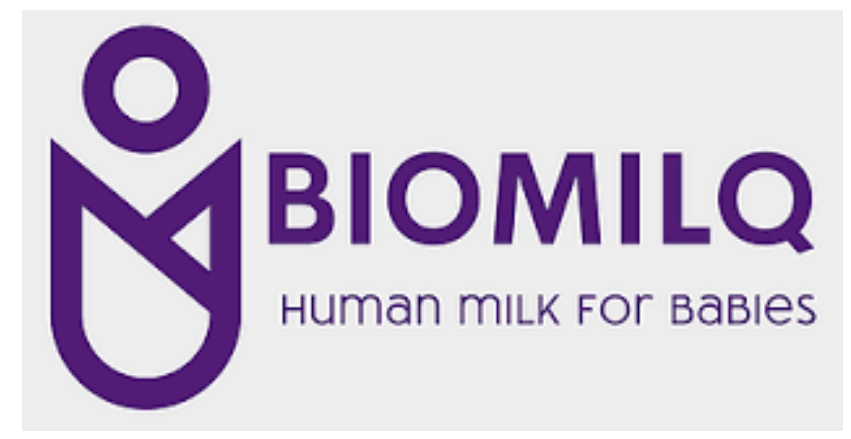

As we can see in their trademark, above, the Biomilq people describe the product they imagine as human milk. They sometimes call it breastmilk. They believe using a few components that came from real breastmilk in the process of making their product makes it breastmilk. There is no foundation for that reasoning in science or in past practice.

Under US law, what we commonly refer to as milk is defined as a "lacteal secretion practically free from colostrum by the complete milking of one or more healthy cows" (Cohen 2019). Surely, if cow's milk is defined as something that comes from cows, breastmilk must be defined as something that comes from human women's breasts. Putting some genuine mammary epithelial cells into something entirely new, produced through cell culture, doesn't make that new product the same as breastmilk.

There are intense ongoing debates about the legal identity of many different kinds of food products. The issues here relating to cell-based foods are comparable to those raised about whether plant-based "meats" really are meat (Beaver and Sylvester 209; Watson 2020d). Biomilq does not have the right to decide that the product they hope to produce will actually be human milk. That issue has not yet been addressed by legal experts and relevant agencies in the 
US or anywhere else. The proposed product is best understood as another form of infant formula, a new type of breastmilk substitute (Kent 2017a, 123-140).

Biomilq is said to be "an artificial breast milk start-up that offers a green alternative to baby formula” (Randall 2020). It certainly is artificial, which in itself means it is not breastmilk. The suggestion that Biomilq would actually be breastmilk is not just wrong; it is likely to be viewed as offensive, dangerous, and perhaps illegal.

\section{MONEY}

What would Biomilq cost to parents? The price is likely to be high because of the complexity of manufacturing, packaging and transporting the product, and also because of the of the need to ensure a substantial return to investors. Would parents have to pay more for Biomilq than they would pay for ordinary infant formula? Would parents be willing to pay a higher price for Biomilq because it supposedly has a smaller environmental impact? Would they believe that Biomilq provides health benefits that justify higher costs?

Infant formula can be expensive, but that is not because it costs a lot to make. The main ingredient of most infant formula is powdered cow's milk, which can be obtained from Alibaba for $\$ 1,200$ a ton (Alibaba 2020). Alibaba also sells several different types powdered formula for between $\$ 2,700$ and $\$ 18,000$ per ton. Whoever packages that powder together with a few other ingredients is likely to sell it for much more than that, as is evident from the prices on packaged and branded infant formula on the Alibaba website. To illustrate, Similac Advance sells for \$10 for a 12-ounce package. That means this formula sells for $\$ 320,000$ per ton. The product is sold for even more on Amazon and other outlets.

Other ingredients in infant formula would cost much more than powdered cow's milk by weight, but they constitute only a small share of the total weight of powdered infant formula. There are also costs for advertising, packaging and shipping. Nevertheless, it is clear that infant formula yields very substantial profits. It is not surprising that manufacturers, wholesalers, and retailers eagerly promote sales of infant formula.

If Biomilq makes it to the marketplace at a retail price comparable to that of currently available infant formula, the formula industry would be likely to drop the price of conventional infant formulas. That could be followed by the industry's offering to buy out and perhaps close down the Biomilq initiative. That could be another way of providing a return on investment for those who have backed it.

\section{BANKED HUMAN MILK}

Some who doubt the merits of the Biomilq initiative say: 
Instead of investing millions in a lab-grown product fraught with technical challenges, those who really want to make a difference should educate women on the unique benefits of breastfeeding. It would also make sense to try to eliminate backward policies in the workplace as well as cultural and other barriers that, for some women, make breastfeeding challenging (Children's Health Defense Team, 2020).

There are other options to consider as well. Biomilq advocates argue that until now women who cannot or choose not to breastfeed have no alternative but to feed with infant formula. They ignore options such as mothers expressing or pumping their own milk, or using wet-nurses.

They also do not mention the possibility of feeding with pasteurized milk from other women, obtained through a human milk bank. Alongside efforts to educate parents and policymakers, money could be invested in efforts to promote the use of banked human milk rather than infant formula. Currently, human milk banks are used primarily to feed premature or critically ill infants such as those in hospitals' neonatal intensive care units (NICUs). Milk bank operations could be expanded to make pasteurized human milk readily available to women who cannot or choose not to breastfeed their infants (Kent 2017b; also see Ballard et al. 2019).

The Biomilq project got \$3.5 million from Breakthrough Energy Ventures, a major investment fund, to support the development of the product. Perhaps another $\$ 3.5$ million could be invested into the pilot projects to develop good ways to extend the reach of human milk banking in different parts of the world. I sketched out the potential in a previous article:

Businesses designed to make human milk more readily available could be set up in low-income as well as high-income countries. There would be a variety of problems to overcome, as in any business startup. If the managers of the project were mainly interested in improving children's health rather than taking home a lot of money, these businesses could lead to substantial benefits for both women and children.

Some of these enterprises could be managed entirely by women. Men could be limited to advisory roles, as determined by the managers.

These enterprises could begin as small pilot projects, with well-chosen advisors who would seek ways to ensure safety and address other concerns. Appropriate bodies of government could develop systems for regulating these enterprises. Transparency in financial arrangements could help to limit abuses.

Such initiatives could lead to the creation of many small businesses. Some would succeed and some would fail, and a great deal would be learned in the process. National governments could establish central offices to oversee them. Global agencies such as UNICEF and the World Health Organization could draw up suitable guidelines for managing human milk banks. (Kent 2017b, 241)

This idea would be acceptable in some societies and not in others. There would be risks of abuse (Fentiman 2010; Kent 2017b; Kent 2019b; Moroney 2017; Smith 2017). These operations, like all milk banks, should be carefully regulated. Relevant regulations should be applied to all types 
of infant formula as well. The Human Milk Banking Association of North America offers excellent guidance (HMBNA 2020).

Pilot projects could be set up to test the concept. People wouldn't reply to the request for proposals unless they felt there was a good chance of success in their cultural settings. The odds of success seem much better than the odds of producing good fake breastmilk.

After a five-year period, the results from those pilot studies could be compared with the results from the Biomilq initiative on every dimension of interest. The findings would help decisionmakers make well-informed judgements on which of these approaches offers the more promising path forward.

\section{REFERENCES}

Alibaba. 2020. Alibaba. Powdered milk.

https://www.alibaba.com/trade/search?fsb=y\&IndexArea=product_en\&CatId=\&SearchT ext=powdered+milk

Ballard, Kiersten, et al. 2019. "Call to Action for Equitable Access to Human Milk for Vulnerable Infants." The Lancet: Global Health. 7 (11): E1484-E1486. https://www.thelancet.com/journals/langlo/article/PIIS2214-109X(19)304024/fulltext\#20

Beaver, Nathan A., and Brian P. Sylvester. 2019. "What's in a Name? The Plant-based Foods Labeling Debate.” Foley. https://www.foley.com/en/insights/publications/2019/10/whatsin-a-name-plant-based-foods-labeling-debate

Biomilq. 2020. Biomilq: Human Milk for Babies. https://www.biomilq.com/ [Also accessible through Breakthrough Energy Ventures website at https://www.b-t.energy/ventures/]

CDC. 2018. Breastfeeding Report Card. Washington D.C.: Centers for Disease Control and Prevention. https://www.cdc.gov/breastfeeding/data/reportcard.htm

Children's Health Defense Team. 2020. More Gates-Funded "Brave New World” Science: Fake Breast Milk.” Children's Health Defense. https://childrenshealthdefense.org/news/moregates-funded-brave-new-world-science-fake-breast-milk/

Cohen, Mathilde. 2019. "Should Human Milk Be Regulated.” UC Irvine Law Review. (9):55764, https://papers.ssm.com/sol3/papers.cfm?abstract_id=3345703

Corbyn, Zoë. 2020. “Should Mother’s Milk be Produced in the Lab?” The Guardian. September 13. https://www.theguardian.com/science/2020/sep/13/should-mothers-milk-beproduced-in-the-lab 
Crowther, SM; LA Reynolds; and EM Tansey. 2009. The Resurgence of Breastfeeding, 19752000. London: Wellcome Trust.

https://www.researchgate.net/publication/32898323_The_resurgence_of_breastfeeding_1 $\underline{975-2000}$

Egger, Michelle; and Leila Strickland. 2020. "Breakthrough: Two Women Producing Breastmilk—Outside the Body.” Medium. https:/medium.com/@BIOMILQ/breakthrough-two-women-produce-breastmilk-outsidethe-body-18dd5a622ac9

Fentiman, Linda C. 2010. "Marketing Mothers' Milk: The Commodification of Breastfeeding and the New Markets for Breast Milk and Infant Formula." Nevada Law Journal (10)1. http://scholars.law.unlv.edu/nlj/vol10/iss1/3/

HMBNA. 2020. Human Milk Banking Association of North America. https://www.hmbana.org/welcome.html\#

IBFAN. 2020. Green Feeding. International Baby Food Action Network. https://www.gifa.org/international/green-feeding/

Invitrogen and Gibco. 2020. Cell Culture Basics Handbook. https://www.google.com/url?sa=t\&rct=j\&q=\&esrc=s\&source=web\&cd=\&cad=rja\&uact= 8\&ved=2ahUKEwic44S2oajqAhXDtp4KHXo_DHUQFjAdegQIChAB\&url=https\%3A\% 2F\%2Fwww.vanderbilt.edu\%2Fviibre\%2FCellCultureBasicsEU.pdf\&usg=AOvVaw0Uts 4tzzBDi8AMtyXXiwSQ

Jordan, Mike. 2020. "Lab-grown Breastmilk Startup Biomilq Raises \$3.5 Million in Seed Funding.” Hypepotamus. https://hypepotamus.com/companies/lab-grown-breastmilkstartup-biomilq-raises-3-5-million-in-seed-funding/

Kent, George. 2017a. Governments Push Infant Formula. Sparsnäs, Sweden: Irene Publishing.

---. 2017b. "Extending the Reach of Human Milk Banking.” World Nutrition. 8(2):232-250. https://worldnutritionjournal.org/index.php/wn/article/view/143/111

---. 2019a. "Comparing Breastfeeding and Feeding with Infant Formula.” World Nutrition. 10 (1):100-118. https://worldnutritionjournal.org/index.php/wn/article/view/612/550

---. 2019b. “Good Questions 7: How Should Human Milk Banks be Regulated?” World Nutrition. 10 (2): 8-26. https://worldnutritionjournal.org/index.php/wn/article/view/636/564

Lamb, Catherine. 2020. "BIOMILQ Has Grown the Main Components of Human Breastmilk in a Lab.” The Spoon. https://thespoon.tech/biomilq-has-grown-the-main-components-ofhuman-breast-milk-in-a-lab/ 
Loffredo, Jeremy; and Michele Greenstein. 2020. "Why the Bill Gates Global Health Empire Promises More Empire and Less Public Health.” The Grayzone. https://thegrayzone.com/2020/07/08/bill-gates-global-health-policy/

Malkan, Stacy. 2020. “Gates’ Failing Green Revolution in Africa.” Ecologist. https://theecologist.org/2020/aug/14/gates-failing-green-revolutionafrica?mc_cid=63f5467423\&mc_eid=80bad9391f

Martyn-Hemphill, Richard. 2020. “These Two Women are Taking the 'Breast' Out of Breastmilk.” Agfunder News. https://agfundernews.com/these-two-women-are-takingthe-breast-out-of-breastmilk.html

Miller, Anna Medaris. 2020. "Lab-made 'human' Breast Milk May Soon be an Option for Parents Who Can't breastfeed But Don't Want to Use Formula.” Business Insider. https://www.businessinsider.in/science/health/news/lab-made-human-breast-milk-maysoon-be-an-option-for-parents-who-cant-breastfeed-but-dont-want-to-useformula/articleshow/76411175.cms

Moroney, Murphy. 2017. "Do You think Women Should be Paid for Donating Breast Milk?” Popsugar. https://www.popsugar.com/family/Should-Women-Paid-Donating-BreastMilk44335179?fb_action_ids=10155759499917534\&fb_action_types=0g.comments\&fbclid= IwAR1011XH3a4bjsfe9mEV2rXAqWQVwFY_59I6Gt99w_ID5hz1U87ZzvZfDDA

Morrison, Pamela. 2018 “How Often Does Breastfeeding Really Fail?” La Leche League International. https://www.llli.org/how-often-does-breastfeeding-reallyfail/?fbclid=IwAR0U6jyBylXljc2rNd4fUUT1vmWYpBNprDS2WGAj9Jxy_K0wybOVc $\underline{B b 1 D U U}$

Peters, Adele. 2020. "Scientists Have Figured Out How to Grow Breast Milk in a Lab.” FastCompany. https://www.fastcompany.com/90464671/scientists-have-figured-outhow-to-grow-breast-milk-in-a-lab?fbclid=IwAR0v48HxymKUQQbIO6JHkVj4rOWDIExAmKAjY2TiU2CUciOlv0Mwh4QV9Q

Peters, Joshua. 2020. "Did these Scientists Just Create the First Lab-grown Human Breast Milk?” New Harvest. https://massivesci.com/articles/cultured-breastmilk-biomilq-new-harvest/

Randall, Ian. 2020. “Artificial Breast Milk Firm that Offers an Environmentally-friendly Alternative to Baby Formula gets $\$ 3.5$ Million From Investment Fund Backed by Bill Gates, Jeff Bezos and Mark Zuckerberg.” Daily Mail. https://www.dailymail.co.uk/sciencetech/article-8439159/Artificial-breast-milk-startgets-3-5-million-Bill-Gates-founded-investment-fund.html

Roy, Aditi. 2020. "Bill Gates' Climate-change Investment Firm Bets on Lab-produced Breast Milk.” CNBC. https://www.cnbc.com/2020/06/16/biomilq-raises-3point5-million-frombill-gates-investment-firm.html 
Schwab, Tim. 2020. “Bill Gates’s Charity Paradox.” The Nation. https://www.thenation.com/article/society/bill-gates-foundation-philanthropy/

Sklar, Julia. 2020. “Can Biotech Startups Make Breast Milk Without the Breast?” The Counter. https://thecounter.org/biotech-breast-milk-infant-formula-biomilq/

Smith, Julie P. 2017. "Without Better Regulation, the Global Market for Breast Milk Will Exploit Mothers.” The Conversation. https://theconversation.com/without-betterregulation-the-global-market-for-breast-milk-will-exploit-mothers79846?utm_source=facebook\&utm_medium=facebookbutton\&fbclid=IwAR3ceifhFPvq wBAomXDLSIWPvm9B6_m8TXE0Nc99hgU_IL7NWsxpfMQUJ1w

Steven, Emily E; Thelma E Patrick; and Rita Pickler. 2009. “A History of Infant Feeding.” Journal of Perinatal Education. 18(2):32-39. https://www.ncbi.nlm.nih.gov/pmc/articles/PMC2684040/

Thorley, Virginia. 2018. “The Trend Towards Breastmilk-feeding: Should we be Concerned?” Breastfeeding Review. 26(1):7-10. https://search.informit.com.au/documentSummary;dn=522293575374067;res=IELAPA

TurtleTree Labs. 2020. Clean Milk for People \& Planet. https://turtletreelabs.com/

USDA. 2020. Research Project: The Mothers, Infants and Lactation Quality (MILQ) Project: A Multi-Center Collaborative Study. United States Department of Agriculture. https://www.ars.usda.gov/research/project/?accnNo=432056

Victora, Cesar; Rajiv Bahl; Aluísio JD Barros; Giovanny VA França; Susan Horton; Julia Krasevec; Simon Murch; Mari Jeeva Sankar; Neff Walker; and Nigel Rollins for The Lancet Breastfeeding Series Group. 2016. "Breastfeeding in the $21^{\text {st }}$ Century: Epidemiology, Mechanisms, and Lifelong Effect.” The Lancet. 387(10017):475-490. https://www.thelancet.com/journals/lancet/article/PIIS0140-6736(15)01024-7/fulltext

Watson, Elaine. 2020a. “BIOMILQ Raises \$3.5m to Fund Mammary Cell Cultured Human Breastmilk Platform, Disrupt Infant Nutrition Market.” Food Navigator USA. https://www.cnbc.com/2020/06/16/biomilq-raises-3point5-million-from-bill-gatesinvestment-firm.html or https://www.foodnavigatorusa.com/Article/2020/06/16/BIOMILQ-raises-3.5m-to-fund-mammary-cell-culturedhuman-breastmilk-platform-disrupt-infant-nutritionmarket?utm_source=newsletter_daily\&utm_medium=email\&utm_campaign=24-Jun2020\#

---. 2020b. "TurtleTree Labs in Talks with Leading Dairy, Infant Formula Brands to License Cell-cultured Human Breastmilk Technology.” Food Navigator USA. https://www.foodnavigator-usa.com/Article/2020/07/01/TurtleTree-Labs-in-talks-withdairy-infant-formula-brands-to-license-cell-cultured-human-breastmilk- 
World Nutrition 2020;11(3):2-11

technology?utm_source=newsletter_daily\&utm_medium=email\&utm_campaign=02-Jul$\underline{2020}$

---. 2020c. "Perfect Day Expands Series C to \$300m; Significantly Boosts Efficiency of Animal Free Dairy Protein Production.” Food Navigator USA. https://www.foodnavigatorusa.com/Article/2020/07/08/Perfect-Day-expands-Series-C-to-300m-significantly-boostsefficiency-of-animal-free-dairy-proteinproduction?utm_source=newsletter_daily\&utm_medium=email\&utm_campaign=08-Jul2020\#

---. 2020d. "USDA to Launch Rulemaking Process for Labeling of Cell-cultured Meat: 'Success Will Turn, in Large measure, on the nomenclature used,' Says Attorney.” Food Navigator USA. https://www.foodnavigator-usa.com/Article/2020/08/04/USDA-tolaunch-rulemaking-and-public-comment-process-for-labeling-of-cell-culturedmeat?utm_source=newsletter_daily\&utm_medium=email\&utm_campaign=04-Aug-2020

WHO. 2018. Infant and Young Child Feeding. Geneva: World Health Organization. http://www.who. int/mediacentre/factsheets/fs342/en/

Wuench, Julia. 2020. "BIOMILQ Could Be the Next Major Food Disruptor: Getting Real About Entrepreneurship With Cofounder and CEO Michelle Egger.” Forbes. https://www.forbes.com/sites/juliawuench/2020/06/22/biomilq-could-be-the-next-majorfood-disruptor-getting-real-about-entrepreneurship-with-co-founder--ceo-michelleegger/\#630019c8a7dd

Zhang, Sarah. 2020. “A Bold and Controversial Idea for Making Breast Milk.” The Atlantic. https://www.theatlantic.com/science/archive/2020/02/lab-grown-breast-milk/606955/ 